\title{
THE INFLUENCE OF INFLATION RATE, BI RATE, AND EXCHANGE RATE CHANGES TO THE FINANCIAL SECTOR STOCK PRICE INDEX RETURN IN THE INDONESIAN STOCK MARKET
}

\author{
Yunita $^{1}$, Robiyanto ${ }^{2 *}$ \\ ${ }^{12}$ Faculty of Economics and Business Satya Wacana Christian University Salatiga 50711, Indonesia \\ *Corresponding author; Email: robiyanto@staff.uksw.edu
}

\begin{abstract}
The objective of this study is to find out how macroeconomic factors such as exchange rate changes, BI rate and inflation rate can affect the financial sector stock price index in IDX from 2011 until 2017. Generalize Autoregressive Conditional Heteroscedasticity (GARCH) is used as the analysis method in this research to find the fittest model. The results are, only exchange rate change that has significant effect to financial sector stock price index. Inflation and BI rate have no significant effect to financial sector stock price index.
\end{abstract}

Keywords: Financial sector stock price index; inflation rate; BI rate; exchange rate.

\section{Introduction}

Nowdays, stock market is one of main choices to invest for the society besides tangible assets such as land and property. Stock market itself can't be freed from country's condition, where a country with good economic condition can increase overall stock price, vice versa. A country's stock market condition can be known from Composite Stock Price Index/ CSPI (Robiyanto, 2018b). Indonesian stock market runs economic function and financial function, where funds are allocated efficiently and the possibility of return gained as the choice of investment.

Stock market meets demands and supplies between people who have excess fund with companies that need fund (Robiyanto, 2018c). Mostly investment is allocated to financial assets such as stocks, obligations, mutual funds, etc. So that, the need of information from society is also increased. One of the information needed is stock price index, that can be accessed from newspaper or even electronic media that is updated everyday as guideline to invest in stock market. Stock price index is often being used to help people to get into stock market, such as government, investors, or academics. This index is found to evaluate the portfolio's performance by managers or financial advisors (Robiyanto, 2017b).

The stock market in Indonesia is known as Bursa Efek Indonesia or Indonesia Stock Exchange (IDX). All companies that listed in IDX is classified to ten sectors depend on kind of industry being run, which one of them is financial sector that is discussed in this study. Financial sector is one of ten sectors in IDX that divided into some sub sectors such as banking, financial institutions, securities, insurance, etc.

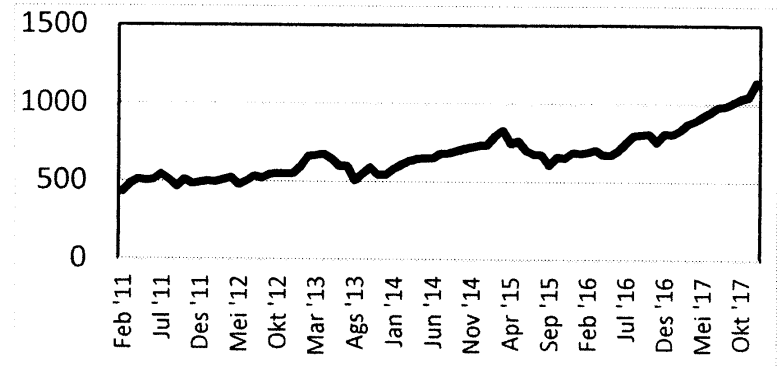

Source: Investing.com (2018)

Figure 1. Monthly closing price of financial sector stock price index from Indonesia Stock Exchange January 2011-December 2017

Financial sector stock price index represent all financial sector stock's movement listed in Indonesia Stock Exchange. As seen in Figure 1, the financial sector stock price index has increased from 2011 to 2017. In 2017 financial sector has played the biggest role in growth to CSPI, with $20.64 \%$ growth. Figure 1 shows that financial stock price index has increased from 2011 to 2017. The higher financial stock index appreciation, the higher financial sector index return. The stock return, especially the financial sector stock return can be influenced by internal factors of the company (this factor is directly related to the fundamental condition or performance of a company) and external factors such as macroeconomic factors (Agustina \& Sumartio, 2014).

There are some studies that explains macroeconomic factors' influence to stock price index return, such as research by (Krisna \& Wirawati, 2013), which found that inflation rate and exchange rate has significant positive effect to composite index return, but research by Triyono and Robiyanto (2017) 
found that exchange rate and $\mathrm{BI}$ rate have significant negative effect to composite index return, and inflation rate has insignificant effect to composite index return. Then research by Kewal (2012) found that only exchange rate that has significant negative effect to composite index and inflation rate and $\mathrm{BI}$ rate have no effect. Amperaningrum and Agung (2011) found that only exchange rate has negative effect on stock price index of banking sub sector, but inflation rate and BI rate have no effect. Utami and Rahayu (2004) found that inflation rate, BI rate and exchange rate has negative effect on composite index significantly. Ginting, Topowijono, and Sulasmiyati (2016) found that inflation rate and BI rate have effect simultantly to banking's stock price index, but inflation do not have any effect partially to index, and exchange rate has effect partially to the index. Robiyanto (2018b) found that BI rate and exchange rate has a significant effect towards Jakarta Islamic Index and Jakarta Composite Index.

The previous findings show that the results are not consistent, mostly because these studies are using multiple regression analysis that is less accurate for analyzing time series data. So that, this research replicates previous researches using exchange rate, BI rate, and inflation rate as independent variable and financial sector's stock price index as dependent variable using GARCH analysis that is more proper in analyzing time series data that is not constant. Time period used in this research is from 2011 until 2017, and the stock price index used is from all financial sector's issuers listed in IDX. In this study, BI rate is used for period before August 2016, while the BI 7-Day Repo Rate is used for period after August 2016. This action been take because effective since August 19 $9^{\text {th }}, 2016$, Bank Indonesia introducing the BI 7-Day Repo, replacing the BI Rate (Harmono, 2017).

The objective in this study is to find out the effectof exchange rate's change, $\mathrm{BI}$ rate and inflation rate to financial sector stock price index in IDX. Hopefully, this research is expected to help decision making based on macroeconomic factors such as inflation rate and exchange rate's change to stock price index, especially in financial sector.

\section{Inflation Rate and the Return of Financial Stock Price Index}

Inflation is a process of increasing prices in general and continuously (related) with the market mechanism that can be caused by various factors (Ernayani, Robiyanto, \& Sudjinan, 2017). When inflation rate gets higher, the cost of living is also increased. Expected inflation rate change affects credit and reinvestments' risk. As a reference, higher infla- tion rate will affect to assets' price. As a result, equity cost will increase, that will cause some project investments are not profitable and affects economy growth and then affect stock market as well (Mokhova \& Zinecker, 2014). Astuti, Prihatini, and Susanta (2013); Mutuku and Ng'eny (2015); Utami and Rahayu (2004) found that inflation rate has negative relation to stock price index. Barakat, Elgazzar, and Hanafy (2016) found that inflation rate has negative effect to stock price index return. So, the hypothesis is:

$H_{l}$ : Inflation rate has negative effect to the return of financial sector stock price index return.

\section{BI Rate and the Return of Financial Stock Price Index}

Interest rate is a loan cost or the price that must be paid for the borrowed fund (Mishkin, 2010). Kurniawati (2015) defines Bank Indonesia's interest rate policy as a policy interest rate that reflects the stance or stance of monetary policy stipulated by Bank Indonesia and announced to the public which spread through the Bank Indonesia's website. The Board of Governors of Bank Indonesia at each monthly Board of Governors Meeting announced and implemented monetary operations through the BI Rate.

The change of interest rate can have negative impact on the stock index return. The higher interest rate, the higher interest cost which could reduce the company's profit. It also makes production cost increased and the products' price could be more expensive so customers will hold their purchase and save their money in bank. The sales will be decreased and it decreases profit so it will have effect on stock price (Raharjo, 2007). Astuti et al. (2013) found that BI rate has a negative effect towards Stock Price Index. Barakat et al. (2016); Martinez, Lapena, and Sotos (2015) also found the same. Robiyanto (2018b); Wiyani (2005) found that BI rate has negative effect towards Jakarta Composite Index return and Jakarta Islamic Index return. So, the hypothesis is:

$H_{2}$ : BI rate has negative effect to financial sector stock price index return

\section{Rupiah Exchange Rate and the Return of Financial Stock Price Index}

According to Joesoef (2008), exchange rate is the amount of one currency that can be exchanged for a unit of another currency. Government (usually through central bank) itself has some policies in exchange rate in order to stabilize its economic condition, such as fixed exchange rate, floating exchange rate, and managed floating rate. Exchange rate change will affect companies' competitiveness, then it will 
impact to its product and its stock price (Arafat, 2016).

If foreign exchange rate increase, the value of domestic currency will decrease (depreciation), so the raw material imported and all imported products will get higher in price, so the production cost will increase and its profit will decrease. But if foreign exchange rate decrease, the value of domestic currency will increase (appreciation) (Ginting et al., 2016). Exchange rate could be volatile, because of changes in demand and supply in foreign exchange market. Kewal (2012) found that Rupiah exchange rate and stock price have an opposite correlation. Astuti et al. (2013); Mardiyati and Rosalina (2013); Robiyanto (2018b), who also found that exchange rate's change has negative effect towards stock price index return. So, the hypothesis is:

$H_{3}$ : Rupiah exchange rate change has negatif effect to the financial sector stock price index return.

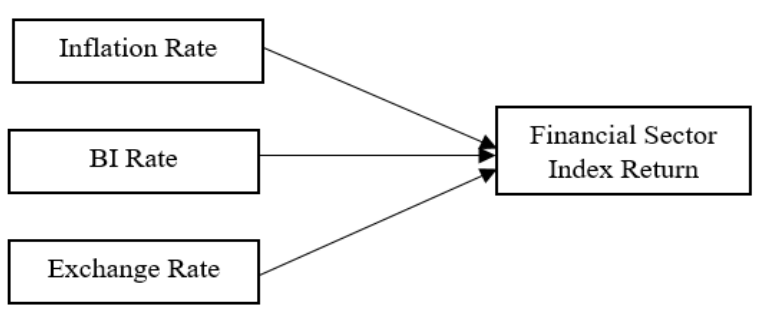

Figure 2. Model framework

\section{Research Method \\ Research Design}

This study is using quantitative method using time series data because the data is obtained from 2011 until 2017 that observes the relation between inflation and exchange rate change towards the return of financial sector stock price index return.

\section{Method of Collecting Data}

The data used in this study is secondary data, where the monthly financial sector stock price index is obtained from Investing.com, from 2011 until 2017. Then, inflation and exchange rate's monthly data is obtained from Central Bank of Indonesia's official website from 2011 until 2017. As mentioned in introduction section, this study also use the 7-days repo rate and $\mathrm{BI}$ rate which obtained from the Bank Indonesia's official website.

\section{Operational Definition of Variables}

In this study, dependent variable used is return of financial sector stock price index, which is calculated with:

$$
R i=\frac{P(t)-P(t-1)}{P(t-1)} \times 100 \%
$$

Remarks:

$R_{i}=$ Return of financial sector stock price index in $t$ period (in percent)

$P_{(t)}=$ Financial sector stock price index in $t$ period (in Rupiah)

$P_{(t-l)}=$ Financial sector stock price index in $t-1$ period (in Rupiah)

And then the independent variable used in this study is inflation rate and exchange rate's change from USD to IDR. The change of exchange rate is calculated with:

$$
\triangle E R=\frac{E R(t)-E R(t-1)}{E R(t-1)} \times 100 \%
$$

Remarks:

$$
\begin{aligned}
\triangle E R= & \text { the change of USD to IDR's exchange rate } \\
& \text { (in percent) } \\
E R_{(t)}= & \text { USD to IDR's exchange rate in } t \text { period (in } \\
& \text { Rupiah) } \\
E R_{(t-l)}= & \text { USD to IDR's exchange rate in } t \text {-period (in } \\
& \text { Rupiah) }
\end{aligned}
$$

\section{Data Analysis Method}

The data analysis method used in this study is Generalize Autoregressive Conditional Heteroscedasticity (GARCH), because this method could modelize residual variance that is not constant (heterocedasticity). This method was introduced by Bollerslev (1986), and the GARCH model used in this study is GARCH $(1,1)$ that is commonly used in some researches done by Cahyaningdyah and Faidah (2017); Robiyanto (2017a, 2018a). Before analyzing the data, root unit with Augmented Dickey Fuller Test must be done first. This GARCH model has advantages in solving residual heterocedasticity so it can be used as a good estimator (Robiyanto, Wahyudi, \& Pangestuti, 2017). This method is better in looking for influence of BI rate, inflation and exchange rate to return of financial sector stock price index. The model of this research is:

$$
\begin{aligned}
& R_{i}=\alpha+\beta_{1}(I R)+\beta_{2}(\Delta E R)+\beta_{3}(B I R)+\varepsilon_{t} \\
& \text { with } \\
& \varepsilon_{t}=\Phi_{t \varepsilon_{t-1}}+\ldots+\Phi_{t} \varepsilon_{t-p}+\eta_{t} \\
& \eta_{t}=\sigma_{t} \\
& \sigma_{2 t}=\alpha 0+\alpha_{l} \eta 2_{t-1}+\ldots+\alpha p \eta_{2 t-p}+\beta_{1} \sigma_{2 t-1}+\ldots+\beta_{q} \sigma_{2}
\end{aligned}
$$

Remarks:

$R_{i}=$ Return of financial sector's stock price index

$I R=$ Inflation rate

$\triangle E R=$ Exchange rate's change

$B I R=$ BI Rate 
$\alpha=$ constant

$\beta=$ beta (regression coefficient)

$\varepsilon_{t} \quad=$ error

$\varepsilon_{t}$ denote a real valued discrete-time stochastic process and is independent and identical distributed $N(0,1)$ and is independent of the past state of $\eta_{t-p}$ or in other words residual is white noise/stationary. Independent and identical distributed has the meaning that a variable (in this case is an error) is not influenced by the data of the past (random) and has the same opportunity to emerge. $\Phi$ is the information set of all information throught time (Bollerslev, 1986).

\section{Result and Discussion}

\section{Descriptive Statistics}

In Table 1 there is descriptive statistics result of financial sector index return that is represented by return along with this study. The highest return obtained is on March 2011, and the lowest return is on August 2013.

\section{Table 1}

Descriptive Statistics of Inflation Rate, Financial Sector Stock Price Index Return, BI Rate and Exchange Rate Change from January 2011- December 2017

\begin{tabular}{|c|c|c|c|c|c|}
\hline Variable Name & $N$ & Min & Max & Mean & Std Dev \\
\hline Inflation & 84 & 0.03 & 0.09 & 0.05 & 0.017 \\
\hline Return & 84 & -0.15 & 0.12 & 0.01 & 0.053 \\
\hline BI Rate & 84 & 0.04 & 0.08 & 0.06 & 0.011 \\
\hline Exchang & 84 & -0.04 & 0.07 & 0.01 & 0.018 \\
\hline Valid $N$ (listwise) & 8 & & & & \\
\hline
\end{tabular}

Source: Bank Indonesia (2018); Investing.com (2018)

\section{Unit Root Test}

The unit root test in this research is using Augmented Dickey Fuller (ADF) Test. The results are seen in Table 2. Based on the result it can be concluded that teher is no unit root and they are stationary so it can be analyzed with GARCH method.

Table 2

Unit Root Test Result

\begin{tabular}{lrrl}
\hline \multicolumn{1}{c}{ Variable } & $\boldsymbol{t}$-statistic & Probability & Result \\
\hline Return & -4.5123 & 0.0004 & Stationary \\
Inflation & -2.4096 & 0.0183 & Stationary \\
BI Rate & 3.3223 & 0.0014 & Stationary \\
Exhange Rate & & & \\
Change & -4.3270 & 0.0000 & Stationary \\
\hline
\end{tabular}

Source: Bank Indonesia (2018); Investing.com (2018)

\section{Robustness Test}

Robustness check is done by using Generalized Error in ML-ARCH (Maximum Likelihood Autoregressive Conditional Heterocedasticity) method (Robiyanto \& Puryandani, 2015). Based on analysis result in Table 3, it is found that GED score 1.632 which is significant at $\alpha=1$ percent. This result shows that $\operatorname{GARCH}(1,1)$ equation is robust. $\operatorname{GARCH}(1,1)$ in the variance equation is significant at $\alpha=1$ percent, that support the result, and shows that residual variance provided will follow GARCH pattern.

\section{GARCH (1,1) Analysis Result}

The analysis result of GARCH $(1,1)$ can be seen on Table 3. Based on the Table 3, it is shown that only one variable has a significant effect toward financial sector stock price index return which is exchange rate change. The effect of exchange rate change toward the financial sector stock price index return is negative, so only $\mathrm{H}_{3}$ that stated exchange rate has negative effect on financial stock return, accepted. The effect is significant at $\alpha=1$ percent, and other variables such as inflation has insignificant effect, and BI rate has insignificant effect to the return. But in GARCH $(1,1)$ result, the GARCH probability is not significant at 0.9995 so the pattern doesn't follow GARCH $(1,1)$ pattern.

\section{Table 3}

GARCH (1,1) Analysis Result

\begin{tabular}{|c|c|c|c|c|}
\hline Variable & Coefficient & Std. Error & $z$-Statistic & Prob. \\
\hline INFLASI & -0.22506 & 0.50394 & -0.44660 & 0.6552 \\
\hline BI_RATE & 0.44862 & 0.39646 & 1.13155 & 0.2578 \\
\hline \multicolumn{5}{|l|}{ EXCHANGE_ } \\
\hline \multicolumn{5}{|l|}{ RATE_CHAN } \\
\hline GE & -0.97728 & 0.39684 & -2.46267 & $0.0138 *$ \\
\hline \multicolumn{5}{|c|}{ Variance Equation } \\
\hline $\mathrm{C}$ & 0.00077 & 0.00070 & 1.09654 & 0.2728 \\
\hline $\operatorname{RESID}(-1)^{\wedge} 2$ & 0.29737 & 0.23147 & 1.28473 & 0.1989 \\
\hline $\operatorname{GARCH}(-1)$ & 0.40547 & 0.43842 & 0.92484 & 0.3550 \\
\hline T-DIST. DOF & 8944.711 & 15830834 & 0.000565 & 0.9995 \\
\hline$R$-squared & 0.07472 & \multirow{2}{*}{\multicolumn{2}{|c|}{$\begin{array}{l}\text { Mean dependent var } \\
\text { S.D. dependent var }\end{array}$}} & 0.01209 \\
\hline $\begin{array}{l}\text { Adjusted } R \text { - } \\
\text { squared }\end{array}$ & 0.05188 & & & 0.05288 \\
\hline S.E. of & 0.05149 & \multirow{2}{*}{\multicolumn{2}{|c|}{$\begin{array}{l}\text { Akaike info } \\
\text { Criterion }\end{array}$}} & \\
\hline regression & & & & 3.04877 \\
\hline $\begin{array}{l}\text { Sum squared } \\
\text { resid }\end{array}$ & 0.21477 & \multicolumn{2}{|c|}{ Schwarz criterion } & 2.84611 \\
\hline Log likelihood & 135.048 & \multicolumn{2}{|c|}{$\begin{array}{l}\text { Hannan-Quinn } \\
\text { criter. }\end{array}$} & 2.96734 \\
\hline $\begin{array}{l}\text { Durbin-Watson } \\
\text { stat }\end{array}$ & 2.16594 & & & \\
\hline
\end{tabular}


And then after doing some trial and error, the most suitable GARCH model to be used in this research's model is GARCH $(1,3)$, where ARCH and GARCH probability is significant at 5 percent and 1 percent. This model was ever used by Kuper (2002) to measure oil price based on the conditional standard deviations, in order to model oil price that is not certain and not constant.

\section{Table 4}

\section{GARCH $(1,3)$ Result}

\begin{tabular}{lrrrr}
\hline \multicolumn{1}{c}{ Variable } & Coefficient & Std. Error & $z$-Statistic & \multicolumn{1}{c}{ Prob. } \\
\hline INFLASI & 0.108339 & 0.315914 & 0.342938 & 0.7316 \\
BI_RATE & 0.276202 & 0.251484 & 1.098290 & 0.2721 \\
EXCHANGE_R & & & & \\
ATE_CHANGE & -0.699560 & 0.188159 & -3.717919 & $0.0002^{* * *}$ \\
\hline \multicolumn{4}{c}{ Variance Equation } \\
\hline C & 0.000284 & 0.000185 & 1.535812 & 0.1246 \\
RESID (-1)^2 & 0.205329 & 0.101178 & 2.029378 & $0.0424^{*}$ \\
GARCH (-1) & 1.492405 & 0.170235 & 8.766723 & $0.0000^{* *}$ \\
GARCH (-2) & -1.410026 & 0.230874 & -6.107331 & $0.0000^{* *}$ \\
GARCH (-3) & 0.612667 & 0.160327 & 3.821370 & $0.0001^{* *}$ \\
\hline GED & & & \\
PARAMETER & 1.632154 & 0.482805 & 3.380567 & 0.0007 \\
\hline R-squared & 0.035129 & Mean dependent var & 0.012099 \\
Adjusted R- & & & \\
squared & 0.011305 & S.D. dependent var & 0.052883 \\
S.E. of & & & \\
regression & 0.052583 & Akaike info criterion & -3.114854 \\
Sum squared & & & \\
resid & 0.223962 & Schwarz criterion & -2.854410 \\
Log likelihood & 139.8239 & Hannan-Quinn criter. & -3.010158 \\
Durbin-Watson & & & \\
stat & 2.074784 & & \\
\hline$*$ * significant at 5\% & & & \\
$* *$ = significant at 1\% & & \\
Source: Bank Indonesia (2018); Investing.com (2018) &
\end{tabular}

Based on GARCH $(1,3)$ model, inflation has insignificant effect with coefficient 0.108339 and probability score 0.7316 . it is similar with studies done by Mardiyati and Rosalina (2013) and Utami and Rahayu (2004) that inflation has insignificant effect towards the financial sector stock price index return. It is happened because the market still accept the condition of inflation under $10 \%$, but if the inflation rate is above $10 \%$, BI rate will also get affected because it gets higher and investors will choose to invest on financial sector stocks (Kewal, 2012). BI rate has an insignificant effect to the financial stock price index return with coefficient 0.276202 and probability 0.2721 .

This result is similar with a study done by Kewal (2012); Mardiyati and Rosalina (2013) that BI rate has an insignificant positive effect towards stock price index, but different with studies done by Astuti et al. (2013); Barakat et al. (2016); Martinez et al. (2015);
Robiyanto (2018b). It is because most investors in Indonesia are doing investment in short term (trading or speculation) so they would rather doing profit taking action than doing investment on SBI (Kewal, 2012). Exchange rate has a significant negative effect to the financial sector stock price index with coefficient -0.6995 and probability 0.0002 . Exchange rate change has negative effect towards the financial sector stock price return. The higher US Dollar appreciation, the lower stock return, on the contrary when the Rupiah appreciated. This result is consistent to Kewal (2012) that Rupiah exchange rate and stock price have an opposite correlation, and consistent with Astuti et al. (2013); Mardiyati and Rosalina (2013); Robiyanto (2018b), who also found that exchange rate change has negative effect towards stock price index.

\section{Conclusion and Recommendation}

\section{Conclusion}

Based on this research, it can be concluded that:

1. It is proven that inflation rate has no effect to financial sector stock price index return empirically.

2. It is proven that BI Rate has no effect to financial sector stock price index return empirically.

3. It is proven that exchange rate change from rupiah to US Dollar has a significant negative effect to financial sector stock price index return empirically.

4. The most suitable GARCH $(p, q)$ model to be used in this research is GARCH (1,3 because all of its $\mathrm{ARCH}$ and GARCH probability is significant at $1 \%$ and $5 \%$ so the pattern follows GARCH $(1,3)$ pattern. The result is the same with GARCH $(1,1)$ pattern where only exchange rate change that has significant negative effect towards financial sector stock price index.

\section{Recommendation}

This study has some limitations, such as the macroeconomic variables used in this study is too common to be used to determine stock price index. So, it is recommended to use other variables such as market risk and gross national product (GNP) and using other sector's stock price index such as manufacture, mining, etc. And also, investor are recommended not to invest in financial sector stock when the value of USD apprecate or Rupiah exchange rate depreciate because of it has negative effect on financial sector stock price index return. 


\section{References}

Agustina, \& Sumartio, F. (2014). Analisa faktor-faktor yang mempengaruhi pergerakan harga saham pada perusahaan pertambangan. Jurnal Wira Ekonomi Mikroskil, 4(1), 51-61.

Amperaningrum, I., \& Agung, R. S. A. (2011). Pengaruh tingkat suku bunga sbi, nilai tukar mata uang dan tingkat inflasi terhadap perubahan harga saham sub sektor perbankan di Bursa Efek Indonesia. Paper presented at the PESAT (Psikologi, Ekonomi, Sastra, Arsitektur \& Sipil), Depok, Indonesia.

Arafat, S. I. (2016). Pengaruh kurs, inflasi, BI rate, dan indeks Dow Jones terhadap Indeks Harga Saham Gabungan (IHSG) di BEI periode 20132015. Undergraduate Thesis, Universitas Widyatama, Bandung, Indonesia.

Astuti, R., Prihatini, A. E., \& Susanta, H. (2013). Analisis pengaruh tingkat suku bunga (sbi), nilai tukar (kurs) Rupiah, inflasi, dan indeks bursa internasional terhadap IHSG (Studi pada IHSG di BEI periode 2008-2012). Jurnal Ilmu Administrasi Bisnis, 2(4), 136-145.

Bank Indonesia. (2018). BI Rate. Retrieved April 1, 2018, from http://www.bi.go. id/id/moneter/birate/data/ Default. aspx.

Barakat, M. R., Elgazzar, S. H., \& Hanafy, K. M. (2016). Impact of macroeconomic variables on stock markets: Evidence from emerging markets. International Journal of Economics and Finance, 8(1), 195-207.

Bollerslev, T. (1986). Generalized autoregressive conditional heteroscedasticity. Journal of Econometrics, 31, 307-327. doi: https://doi.org/10. 1016/ 0304-4076(86)90063-1.

Cahyaningdyah, D., \& Faidah, F. (2017). Analisis pengaruh hari perdagangan terhadap return saham di Bursa Efek Indonesia: Pengujian menggunakan GARCH (Generalized Autoregressive Conditional Heterocedasticity). Ekspektra: Jurnal Manajemen dan Bisnis, 1(1), 1-10.

Ernayani, R., Robiyanto, R., \& Sudjinan, S. (2017). Factors influencing profit distribution management of sharia commercial banks in Indonesia. Journal of Economics, Business \& Accountancy Ventura, 20(2), 187-192. doi: 10. 14414/jebav. v20i2.1055.

Ginting, M. R. M., Topowijono, \& Sulasmiyati, S. (2016). Pengaruh tingkat suku bunga, nilai tukar dan inflasi terhadap harga saham. Jurnal Administrasi Bisnis, 35(2), 77-85.

Harmono, H. (2017). Relationship between macroeconomics fundamentals, bank credit scheme, firms performance, and firms value dimensions. Jurnal Keuangan dan Perbankan 21(1), 82-94.

Investing.com. (2018). IDX finance (JKFINA) Retrieved April 1, 2018, from https://www.investing. com/indices/idx-finance.

Joesoef, J. R. (2008). Pasar uang \& pasar valuta asing. Jakarta: Salemba Empat.

Kewal, S. S. (2012). Pengaruh inflasi, suku bunga, kurs, dan pertumbuhan pdb terhadap indeks harga saham gabungan. Jurnal Economia, 8(1), 53-64.

Krisna, A. A. G. A., \& Wirawati, N. G. P. (2013). Pengaruh inflasi, nilai tukar Rupiah, suku bunga sbi pada indeks harga saham gabungan di BEI. Jurnal Akuntansi Universitas Udayana, 3(2), 421-435.

Kuper, G. H. (2002). Measuring oil price volatility. SSRN Electronic Journal, 1-19. Retrieved June 1, 2018 from https://ssrn. com/abstract=316480

Kurniawati, E. (2015). Analisis pengaruh nilai tukar (kurs) Dolar Amerika/Rupiah (US\$/RO), inflasi, bi rate, dan jumlah uang beredar terhadap harga saham pada perusahaan perbakan yang terdaftar di Bursa Efek Indonesia periode 2013. Skripsi, Universitas Muhammadiyah Surakarta, Surakarta.

Mardiyati, U., \& Rosalina, A. (2013). Analisis pengaruh nilai tukar, tingkat suku bunga dan inflasi terhadap indeks harga saham: Studi kasus pada perusahaan properti yang terdaftar di Bursa Efek Indonesia. Jurnal Riset Manajemen Sains Indonesia, 4(1), 1-15.

Martinez, P. M., Lapena, R. F., \& Sotos, F. E. (2015). Interest rate changes and stock returns in Spain: A wavelet analysis. Business Research Quarterly, 18, 95-110.

Mishkin, F. S. (2010). Ekonomi uang, perbankan, dan pasar keuangan (vol. 1). Jakarta: Salemba Empat.

Mokhova, N., \& Zinecker, M. (2014). Macroeconomic factors and corporate capital structure. Procedia - Social and Behavioral Sciences, 110, 530-540.

Mutuku, C., \& Ng'eny, K. L. (2015). Macroeconomic variables and the Kenyan equity market: A time series analysis. Business and Economic Research, 5 (1), 1-10.

Raharjo, S. (2007). Analisis pengaruh variabel ekonomi makro dan rasio keuangan terhadap harga saham. Working Paper.

Robiyanto, R. (2017a). Month of the year effect pada pasar obligasi di Indonesia. Jurnal Ekonomi dan Bisnis, 20(2), 291-302. doi: 10.24914/jeb.v20 i2.1093. 
(2017b). Performance evaluation and risk aversion rate for several stock indices in Indonesia Stock Exchange. Jurnal Manajemen dan Kewirausahaan, 19(1), 60-64. doi: 10.9744/ jmk.19.1.60-64

, (2018a). The dynamic correlation between ASEAN-5 stock markets and world oil prices. Jurnal Keuangan dan Perbankan, 22(2), 198210.

(2018b). The effect of gold price changes, usd/idr exchange rate changes and Bank Indonesia (BI) rate on Jakarta Composite Index (JCI)'s return and Jakarta Islamic Index (JII)'s return. Jurnal Manajemen dan Kewirausahaan, 20(1), 45-52. doi: https://doi.org/10.9744/jmk. 20. $1.45-52$.

, (2018c). Performance Evaluation of Stock Price Indexes in the Indonesia Stock Exchange. International Research Journal of Business Studies, 10(3), 173-182. doi: https://doi.org/10. 21632/irjbs.10.3.173-182.

Robiyanto, R., \& Puryandani, S. (2015). The Javanese lunar calendar's effect on Indonesian stock returns. Gadjah Mada International Journal of Business, 17(2), 125-137. doi: 10. 22146/ gama ijb.6906.
Robiyanto, R., Wahyudi, S., \& Pangestuti, I. R. D. (2017). The volatility-variability hypotheses testing and hedging effectiveness of precious metals for the Indonesian and Malaysian capital markets. Gadjah Mada International Journal of Business, 19(2), 167-192. doi: 10.22146/ga maijb.26260.

Triyono, D., \& Robiyanto, R. (2017). The effect of foreign stock indexes and Indonesia's macroeconomics variables toward Jakarta Composite Stock Price Index (JCI). Advanced Science Letters, 23(8), 7211-7214. doi: https://doi.org/10. 1166/asl. 2017.9332.

Utami, M., \& Rahayu, M. (2004). Peranan profitabilitas, suku bunga, inflasi dan nilai tukar dalam mempengaruhi pasar modal Indonesia selama krisis ekonomi. Jurnal Manajemen dan Kewirausahaan, 5(2), 123-131.

Wiyani, W. (2005). Pengaruh nilai tukar Rupiah, tingkat suku bunga deposito dan volume perdagangan saham terhadap harga saham. Jurnal Keuangan dan Perbankan, 9(3), 884-903. 